\title{
Pengembangan E-Modul dengan Flipbook pada Mata Pelajaran Simulasi dan Komunikasi Digital
}

\section{Inkha Ameriza1*, Nizwardi Jalinus ${ }^{2}$}

1,2 Jurusan Pendidikan Teknologi Kejuruan, Universitas Negeri Padang, Padang, Indonesia

\section{ART I C L E I N F O}

\section{Article history:}

Received August 26, 2021

Revised August 28, 2021

Accepted September 30, 2021

Available online December 25, 2021

Kata Kunci:

Pengembangan E-Modul, Simulasi

dan Komunikasi Digital

Keywords:

E-Module Development, Simulation and Digital Communication

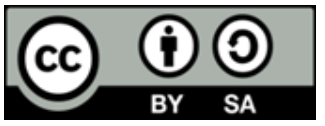

This is an open access article under the CC BY-SA license.

Copyright () 2021 by Author. Published by Universitas Pendidikan Ganesha.

\begin{abstract}
A B S T R A K
Siswa kurang memahami pelajaran simulasi dan komunikasi digital karena pelajarannya terdapat praktikum serta sumber belajar lain termasuk buku kurang dapat dimanfaatkan oleh siswa. Akibatnya, hasil belajar siswa menjadi kurang maksimal. Penelitian ini bertujuan untuk menghasilkan e-modul yang valid, praktis, dan efektif digunakan pada pelajaran simulasi dan komunikasi digital. Penelitian ini adalah penelitian research and Development (R\&D) yang merujuk pada model pengembangan 4D. Adapun subjek penelitian ini adalah siswa kelas X TKJ pada mata pelajaran simulasi dan komunikasi digital dan terdiri dari 36 orang siswa. Teknik analisis data yang digunakan dengan mendekripsikan kevali dan kepraktisan dan keefektifan pada media pembelajaran yang dikembangkan. Hasil yang diperoleh dari penelitian pengembangan ini adalah e-modul sebagai sarana untuk pembelajaran yang bisa didapatkan siswa melalui google classroom. Berdasarkan hasil hasil analisis data dapat disimpulkan bahwa media yang dikembangkan dinyatakan valid pada aspek media $92 \%$ dan aspek materi dengan hasil $91 \%$. Media yang dikembangkan praktis dengan nilai kepraktisan dari respon guru dengan hasil $92,78 \%$ dan respon siswa $91,25 \%$ serta efektif dalam meningkatkan pemahaman siswa yang diperoleh dari perhitungan ketuntasan klasikal yang diperoleh dengan diatas $\mathrm{KKM} \geq 75$ dengan hasil $89 \%$. Jadi, e-modul flipbook untuk mata pelajaran Simulasi dan Komunikasi Digital dinyatakan valid, praktis, dan efektif.
\end{abstract}

\section{A BS TRACT}

Students do not understand about simulation lessons and digital communication, because the lessons have practicum and other learning resources including books that cannot be used by students, as a result, student learning outcomes are less than optimal. This study aims to produce e-modules that are valid, practical and effective for use in simulation lessons and digital communication. This research is a research and development $(R \& D)$ research which refers to the $4 D$ development model. The subjects of this research are XTKJ class students in simulation and digital communication subjects and consist of 36 students. The data analysis technique used is to describe the validity and practicality and effectiveness of the developed learning media. The results obtained from this development research are e-modules as a means for learning that can be obtained by students through Google Classroom. Based on the findings of this researcher, it can be concluded that the media developed was declared valid on the media aspect $92 \%$, the material aspect with $91 \%$ results. The media that was developed was practical with the practicality value of the teacher's response with the results of $92.78 \%$ and $91.25 \%$ student responses, and was effective in increasing student understanding obtained from classical completeness calculations obtained with KKM above 75 with $89 \%$ results. So, the flipbook e-module for Simulation and Digital Communication subjects is declared valid, practical and effective

\section{PENDAHULUAN}

Pandemi Covid-19 memberikan pukulan yang sangat besar terhadap pendidikan di Indonesia. Kondisi ini menuntut pemerintah mengadopsi peraturan dan memberikan tindakan cepat untuk 
mencegah penyebarannya (Khachfe et al., 2020). Kebijakan yang diambil oleh pemerintah adalah meminta kepada seluruh perguruan tinggi, SMA/SMK, SMP, dan SD melakukan pembelajaran online di samping segala aktivitas yang melibatkan orang banyak seperti seminar, loka karya, study banding dan koferensi (Mishra et al., 2020; Oyedotun, 2020; Patricia, 2020; Sahu, 2020). Segala kebijakan yang dilakukan oleh pemerintah untuk mencegah terjadinya perluasan penyebaraan. Salah satu cara yang bisa dilakukan untuk tetap mencapai tujuan pembelajaran adalah pembelajaran online. Pembelajaran daring adalah salah satu solusi yang bisa dilakukan dalam proses pembelajaran saat ini karena dengan adanya pembelajaran daring/online peserta didik tetap memperoleh materi yang harus mereka dapat tanpa dalam satu ruangan. Pembelajaran daring memberikan kesempatan peserta didik untuk bertukar pendapat dengan orang lain dan memberikan kesempatan kepada peserta didik untuk belajar mandiri (Hwang et al., 2020). Alat bantu yang bisa digunakan dalam proses pembelajaran daring adalah google meet, google room, google classroom, WA, dan social media (Chang et al., 2020). Salah satu alat pembelajaran yang digunakan adalah Google classroom. Google classroom adalah aplikasi yang dibuat oleh google yang bertujuan untuk membantu guru dan peserta didik apabila kedua hal tersebut berhalangan, mengorganisasi kelas serta berkomunikasi dengan peserta didik tanpa harus terikat dengan jadwal di kelas. Google classroom dirancang untuk membantu pendidik membuat dan mengumpulkan tugas tanpa kertas(Nirfayanti \& Nurbaeti, 2019; Rahmanto \& Bunyamin, 2020). Google Classroom benar-benar mampu menjadi fasilisator bagi siswa dalam belajar (Qholby \& Lazulva, 2020). Penggunaan google classroom akan membuat pembelajaran menjadi lebih efektif terlebih lagi guru dan siswa bisa setiap saat bertatap muka melalui kelas online google classroom (Soni et al., 2018).

Adanya pembelajaran dengan bantuan google classroom memang mempermudah proses pembelajaran di tengah pandemi. Ada beberapa kendala yang dihadapi dalam proses pembelajaran secara online, yaitu berkurangnya interaksi dalam proses pembelajaran. Artinya, pada pembelajaran online tidak terjadi interaksi social sesama peserta didik (Dong et al., 2020). Banyak anak yang tidak melakukan pembelajaran online, tetapi mereka melakukan aktivitas yang lain selain belajar seperti bermain game, social media, lebih banyak menonton youtube, serta kegiatan yang lain yang menunjukkan adanya kecanduan "gawe" (Liu et al., 2020; Rahmawati \& Latifah, 2020; Samaha \& Hawi, 2016). Hal ini sesaui dengan hasil analisis awal yang dilakukan, yaitu pada saat masa pandemi ini siswa belajar dengan menggunakan smartphone, sedangkan sebelum pandemi siswa belajar dan berpanduan kepada buku cetak dan tidak mencari referensi lain. Bahan ajar cetak hanya disajikan bergantung kepada kehadiran guru. Jika guru tidak hadir maka sumber belajar lain termasuk buku pun kurang dapat dimanfaatkan oleh peserta didik. Akibatnya, hasil belajar siswa menjadi kurang maksimal. Di samping itu, masa new normal saat pandemi menjadikan pembelajaran semester selanjutnya dilakukan secara daring. Siswa hanya belajar dengan menggunakan buku cetak, jobsheet, dan powerpoin yang dikirimkan guru melalui google classroom. Dengan demikian, siswa kurang memahami pelajaran Simulasi dan Komunikasi Digital karena dalam pelajaran ini terdapat praktikum. Jika kondisi ini dibiarkan akan berdampak tidak baik terhadap hasil belajar siswa. Oleh sebab itu, dibutuhkan sebuah solusi dari masalah tersebut. Salah satu solusinya adalah dengan mengembangkan modul pembelajaran.

Modul ini merupakan salah satu konsep bahan ajar yang dikemas secara lengkap dan sistematis yang di dalamnya berisi seperangkat pengalaman belajar yang dirancang dan dikembangkan untuk membantu siswa mencapai tujuan pembelajaran yang spesifik (Samsu et al., 2020). Modul adalah salah satu bahan ajar yang dapat digunakan dalam membantu proses pembelajaran (Diana et al., 2018). Sebuah modul akan bermakna jika peserta didik dapat dengan mudah menggunakannya (Pratiwi et al., 2017). Saat ini modul yang banyak dikembangkan dan sesuai dengan kondisi saat ini adalah e-modul. E-modul merupakan modul elektronik yang disajikan dengan komputer. E-Modul dapat menampilkan teks, gambar, animasi, dan video melalui perangkat elektronik berupa computer (Imansari \& Sunaryantiningsih, 2017). E-modul yang sangat diperlukan oleh siswa dan guru sebagai sumber belajar interaktif untuk pembelajaran di kelas (Fauziah et al., 2016). E-modul yang dikembangkan dengan perpaduan media pembelajaran melalui google classroom, hampir sama dengan modul cetak tapi berbedanya adalah pada $e$ modul yang ada di dalamnya. Untuk mempermudah penggunaan e-modul maka dibutuhkan sebuah aplikasi. Dalam penelitian ini salah satu aplikasi yang digunakan adalah flipbook. Beberapa penelitian yang sudah dilakukan berkaitan dengan e-modul flipbook, antara penelitian yang menyatakan bahwa emodul berbasis FlipBook Maker pada materi Pendidikan Karakter efektif untuk penguatan karakter mahasiswa dan juga efektif dalam meningkatkan hasil belajar (Asmi et al., 2018). Penelitian yang menyatakan bahwa setelah melakukan uji kelayakan terhadap e-modul Termodinamika berbasis Flipbook Maker menggunakan uji validasi dengan lembar validasi oleh dua ahli materi dan dua ahli media maka diidapatkan hasil e-modul Termodinamika berbasis Flipbook Maker ini layak untuk digunakan (Mukramah et al., 2020). Penelitian yang menyatakan bahwa perbedaan hasil belajar pemrograman dasar siswa pada kelas bahan ajar e-modul E-Modul Berbasis Flipbook dan dengan kelas bahan ajar cetak 
(Nurhidayati et al., 2018). Penelitian yang menyatakan bahwa modul elektronik (e-modul) berbasis HOTS berbantuan Flipbook Marker menjadi produk jadi yang layak digunakan (Puspitasari et al., 2020). Jadi, adanya e-modul flipbook dapat memberikan pengaruh yang positif terhadap proses pembelajaran. Berdasarkan hal tersebut penelitian pengembangan yang bertujuan untuk menghasilkan e-modul yang valid, praktisdan efektif digunakan pada pelajaran simulasi dan komunikasi digital.

\section{METODE}

Jenis penelitian yang dilakukan adalah penelitian dan pengembangan atau Research and Development (R\&D). Penelitian ini dilakukan untuk menghasilkan produk atau menyempurnakan sebuah produk yang telah ada dengan terlebih dahulu dilakukan uji coba pada produk tersebut untuk memperoleh keefektifan produk. Produk yang dimaksud berupa e-modul pada mata pelajaran Simulasi dan Komunikasi Digital. Jenis penelitian ini dipilih karena sesuai untuk mengembangkan sebuah media yang mempunyai tujuan untuk mengembangkan dan memvalidasi produk. Pengembangan dilakukan dengan menggunakan model 4D yang dikemukakan oleh Thiagarajan pada tahun 1974. Kecocokan model 4D dalam penelitian ini karena model 4D tepat digunakan untuk mengembangkan perangkat yapembelajaran. Tahap-tahap yang dimilikinya lebih sistematis dan terperinci mencakup semua aspek yang harus dianalisis. Thiagarajan mengelompokkan model ini menjadi 4 langkah tahapan yaitu define, design, develop, dan disseminate.

Tahap Define merupakan tahap awal seperti melakukan analisis peserta didik, kurikulum, dan konsep. Analisis kurikulum dilakukan untuk melihat kesesuaian materi ajar yang dibahas dan kompetensi inti mata pelajaran, tujuan pembelajaran, mengkaji silabus, dan strategi pembelajaran yang cocok, serta meninjau ulang literatur yang terkait dengan e-modul. Analisis peserta didik bertujuan untuk melihat kemampuan peserta didik, latar belakang pengetahuan hingga kemampuan kognitif. Analisis konsep dilakukan untuk pemilihan materi yang sesuai serta strategi pembelajaran yang tepat. Tahap design dilakukan perancangan e-modul dengan memerhatikan pokok bahasan yang sesuai dengan indikator serta tujuan pembelajaran. Kegiatan utama dari tahap ini adalah menulis, menelaah, dan mengedit emodul yang dirancang dengan memerhatikan bahasa, susunan kata, format tujuan, evaluasi dan gambar, video, audio dan animasi. Tahap develop adalah tahap untuk menciptakan e-modul yang dikembangkan sesuai dengan hasil revisi berdasarkan saran validator hingga memperoleh e-modul yang valid dan layak di uji coba. Pada tahap tahap develop ini dilakukan beberapa uji, yaitu: Uji Validitas Produk. Agar menghasilkan produk yang valid, produk yang dihasilkan pada tahap design harus divalidasi. Validasi produk dilakukan oleh pakar yang ahli dibidang kajiannya. Para pakar dan praktisi tersebut kemudian disebut dengan validator. Validator ditentukan sesuai dengan keahlian validator pada bidang keahliannya. Uji Praktikalitas. Untuk melihat tingkat kemudahan dalam penggunaan, efisiensi waktu, dan daya tarik dan minat peserta didik dalam menggunakan e-modul. Praktikalitas dimaksudkan untuk menguji tingkat keterpakaian e-modul oleh guru dan peserta didik ketika pembelajaran. Uji efektivitas. Untuk melihat apakah e-modul yang dibuat efektif dalam meningkatkan hasil belajar peserta didik. Uji efektivitas dilakukan pada akhir pembelajaran setelah menggunakan e-modul dengan melakukan tes kognitif. Tahap Disseminate dilakukan penyebaran terhadap e-modul yang telah dikembangkan. Syarat dilakukan penyebaran apabila e-modul yang di kembangkan sudah valid, praktis dan efektif dari validator dan uji coba yang dilakukan.

Teknik pengumpulan data menggunakan observasi dan angket. Observasi digunakan untuk mengetahui kebutuhan media pembelajaran yang dikembangkan yaitu berupa E-Modul. Angket berisi penilaian kelayakan media oleh ahli media, ahli materi, guru pengampu, dan siswa sebagai pengguna. Proses Pengumpulan data menggunakan instrumen penelitian yang terdiri dari lembar observasi dan angket. Lembar observasi dilakukan dengan mengamati nilai siswa dan proses pembelajaran, sehingga hasil pengamatan sebagai acuan dalam pembuatan media pembelajaran. Lembar angket digunakan untuk menggukur kelayakan media. Data dianalisis secara deskriptif kualitatif dan kuantitatif. Data kualitatif berupa data deskriptif yang diperoleh dari hasil validasi oleh para ahli, hasil yang diperoleh digunakan sebagai acuan revisi produk. Data kuantitatif diperoleh dari mengubah data kualitatif menggunakan skala likert dengan skala 4 (baik sekali), 3 (baik), 2 (cukup), dan 1 (kurang). Media pembelajaran berbasis android yang dikembangkan dikatakan efektif dilihat berdasarkan dari hasil belajar siswa yang terdiri dari peningkatan hasil belajar dan ketuntasan hasil belajar. Peningkatan hasil belajar menggunakan rumus uji $N$ gain. Gain score dinormalisasikan merupakan metode yang baik untuk menganalisis hasil prestest dan posttest. Gain score merupakan indikator yang baik untuk menunjukkan tingkat keefektifan pembelajaran yang dilakukan dilihat dari skor pretest dan posttest. 


\section{HASIL DAN PEMBAHASAN}

Hasil yang didapat adalah produk E-Modul pembelajaran yang valid, praktis, dan juga efektif digunakan pada mata pelajaran Simulasi dan Komunikasi Digital di jurusan Teknik Komputer dan Jaringan SMK N 6 Sumatera Barat. Modul elektronik yang dihasilkan adalah modul dalam bentuk aplikasi elektronik yang berisikan media pembelajaran seperti suara, animasi, video, dan suara. Modul ini memiliki alat evaluasi pembelajaran secara mandiri yang dapat diakses secara online dan offline menggunakan smart phone dan laptop sebagai perangkat pengakses. Hasil produk yang dihasilkan ditunjukkan pada gambar 1 dan 2. Produk yang dihasilkan kemudian diuji validitas materi dan validitas media. Hasil validasi dari para ahli media terhadap media pembelajaran E-Modul adalah sebagi berikut. Hasil validasi menunjukkan bahwa media pembelajaran E-Modul ini memiliki nilai kevalidan 0,91>0,66 yang diberikan validator ke-1 dan nilai kevalidan 0,99>0,66 yang diberikan oleh validator ke-2. Ini berarati bahwa media pembelajaran E-Modul termasuk kategori valid. Sedangkan hasil validasi materi media pembelajaran emodul memiliki nilai kevalidan 0,89>0,66 yang diberikan oleh validator ke-1 dan nilai kevalidan 0,93>066 yang diberikan oleh validator ke-2. Hasil ini menunjukkan bahwa materi pada media pembelajaran berbasis android termasuk pada kategori valid. Rata-rata penilaian kepraktisan yang berasal dari respon guru yaitu 95\% dan 90,88\% respon siswa. Dengan demikian dapat disimpulkan bahwa media pembelajaran e-modul tersebut masuk pada kategori "Sangat Praktis". Uji yang terakhir adalah uji efektivitas. Dari hasil uji efektivitas diperoleh bahwa ketuntasan klasikal mencapai 86\% dan niali gain score 0,66 dengan kategori sedang. Dapat disimpulkan bahwa media pembelajaran dengan e-modul dinyatakan efektif.

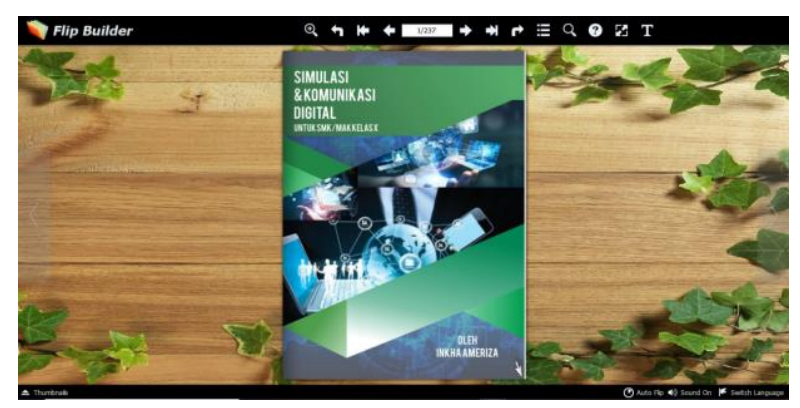

Gambar 1. Hasil Produk Tampilan Cover

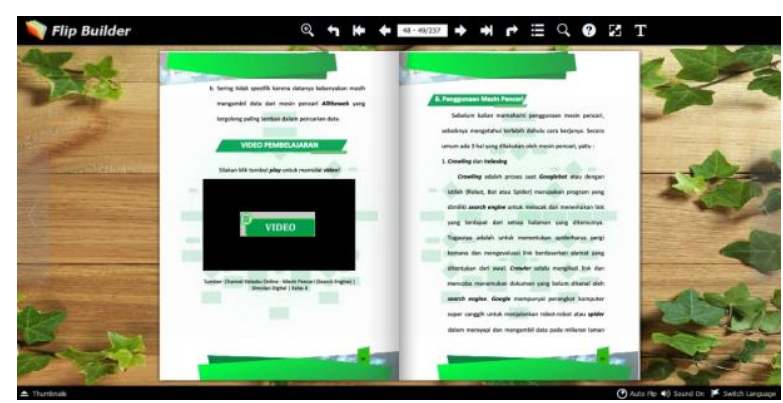

Gambar 2. Hasil Produk Tampilan Isi

Berdasarkan hasil tersebut dapat diakatakan bahwa e-modul flipbook untuk mata pelajaran Simulasi dan Komunikasi Digital dinyatakan valid, praktis, dan efektif. Hal ini tidak terlepas dari pemanfaatan bahan e-modul ini dikembangkan. Kelayakan media pembelajaran dapat dilihat dari segi materi pembelajaran. Media pembelajaran dibuat dengan mereview materi sesuai dengan kurikulum 2013. Dengan menganalisis materi sesuai dengan kurikulum 2013, media pembelajaran dapat digunakan sesuai dengan tujuan pembelajaran kurikulum 2013. Kelayakan media pembelajaran interaktif berbasis powerpoint adalah sebagai berikut. Dilihat dari segi desain pembelajaran, media pembelajaran interaktif dikembangkan dengan mempertimbangkan karakteristik siswa. Penggunaan media pembelajaran yang sesuai dengan karakteristik siswa dalam pembelajaran membantu siswa memahami mata pelajaran yang abstrak serta meningkatkan hasil belajar dan kinerjanya (Khamidah et al., 2019; Novita \& Novianty, 2020). Dalam pengembangannya, media ini menampilkan visual disukai siswa. Penambahan unsur animasi pada media pembelajaran interaktif yang dikembangkan dapat membuat siswa senang saat belajar (Alannasir, 2016; Reswita dan Sri Wahyuni, 2018). E-Modul dapat menampilkan teks, gambar, animasi, dan video melalui perangkat elektronik berupa computer (Imansari \& Sunaryantiningsih, 2017). Dengan adanya modul yang menarik akan membuat siswa menjadi lebih tertarik untuk belajar, hal ini juga dapat mempengaruhi dan meningkatkan hasil belajar siswa (Hakim \& Windayana, 2016; Putri et al., 2019). Selain itu, media pembelajaran interaktif yang dikembangkan diprogram untuk memasukkan unsur-unsur pembelajaran. Melalui pemrograman ini telah dikembangkan media pembelajaran untuk membantu guru memberikan materi dan membantu siswa memahami topik (Pramudita et al., 2018). Modul adalah salah satu bahan ajar yang dapat digunakan dalam membantu proses pembelajaran (Diana et al., 2018). Sebuah modul akan bermakna jika peserta didik dapat dengan mudah menggunakannya (Pratiwi et al., 2017). E-modul yang sangat diperlukan bagi siswa dan guru sebagai sumber belajar interaktif untuk pembelajaran di kelas (Fauziah et al., 2016). Beberapa penelitian yang sudah dilakukan berkaitan dengan e-modul flipbook, antara penelitian yang menyatakan bahwa e-modul berbasis FlipBook Maker pada materi Pendidikan Karakter efektif untuk penguatan karakter mahasiswa dan juga efektif dalam meningkatkan hasil belajar (Asmi et al., 2018). Penelitian yang menyatakan bahwa Setelah melakukan uji kelayakan terhadap e-modul Termodinamika berbasis Flipbook Maker menggunakan uji 
validasi dengan lembar validasi oleh dua ahli materi dan dua ahli media maka diidapatkan hasil e-modul Termodinamika berbasis Flipbook Maker ini layak untuk digunakan (Mukramah et al., 2020). Penelitian yang menyatakan bahwa perbedaan hasil belajar pemrograman dasar siswa pada kelas bahan ajar emodul E-Modul Berbasis Flipbook dan dengan kelas bahan ajar cetak (Nurhidayati et al., 2018). Penelitian yang menyatakan bahwa modul elektronik (e-modul) berbasis HOTS berbantuan Flipbook Marker menjadi produk jadi yang layak digunakan (Puspitasari et al., 2020). Jadi, adanya e-modul flipbook dapat memberikan pengaruh yang positif terhadap proses pembelajaran.

\section{SIMPULAN}

E-modul flipbook untuk mata pelajaran Simulasi dan Komunikasi Digital dinyatakan valid, praktis, dan efektif dilihat dari aspek materi dan media dengan katagori sangat baik, sangat praktis, dan efektf dalam upaya meningkatkan hasil belajar siswa. Hal ini dapat dilihat dari ketuntasan siswa. E-modul flipbook dapat memberikan pengaruh yang positif terhadap proses pembelajaran, sehingga modul ini bisa digunakan sebagai salah satu bahan ajar.

\section{DAFTAR RUJUKAN}

Alannasir, W. (2016). Pengaruh Penggunaan Media Animasi dalam Pembelajaran IPS terhadap Motivasi Belajar Siswa Kelas IV SD Negeri Mannuruki. Journal of Educational Science and Technology (EST), 2(2), 81. https://doi.org/10.26858/est.v2i2.2561.

Areni, I. S., Amirullah, I., Muslimin, Z., \& ... (2019). Pengenalan Pembelajaran Interaktif Berbasis Game di SDN 14 Bonto-Bonto Kabupaten Pangkep. Panrita Abdi-Jurnal ..., 3(2), 177-183. https://doi.org/0000-0002-6248-3656.

Asmi, A. R., Dhita Surbakti, A. N., \& C., H. (2018). E-Module Development Based Flip Book Maker for Character Building in Pancasila Coursework Sriwijaya University. Jurnal Pendidikan Ilmu Sosial, 27(1), 1. https://doi.org/10.17509/jpis.v27i1.9395.

Chang, T. Y., Hong, G., Paganelli, C., Phantumvanit, P., Chang, W. J., Shieh, Y. S., \& Hsu, M. L. (2020). Innovation of Dental Education during COVID-19 Pandemic. Journal of Dental Sciences, 155. https://doi.org/10.1016/j.jds.2020.07.011.

Diana, M., Netriwati, N., \& Suri, F. I. (2018). Modul Pembelajaran Matematika Bernuansa Islami dengan $\begin{array}{lllll}\text { Pendekatan Inkuiri. Desimal: Jurnal Matematika, } & \text { 1(1), }\end{array}$ https://doi.org/10.24042/djm.v1i1.1906.

Dong, C., Cao, S., \& Li, H. (2020). Young Children's Online Learning during COVID-19 Pandemic: Chinese Parents' Beliefs and Sttitudes. Children and Youth Services Review, 118(June), 105440. https://doi.org/10.1016/j.childyouth.2020.105440.

Fauziah, I. Z., Sutrisno, \& Suwarni. (2016). Pengembangan E-Modul Berbasis Adobe Flash CS6 pada Mata Pelajaran Penataan Barang Dagang. Jurnal Pendidikan Bisnis Dan Manajemen, 2(2), 154-159. http://journal2.um.ac.id/index.php/jpbm/article/view/1703.

Hakim, A. R., \& Windayana, H. (2016). Pengaruh Penggunaan Multimedia Interaktif dalam Pembelajaran Matematika untuk Meningkatkan Hasil Belajar Siswa SD. EduHumaniora / Jurnal Pendidikan Dasar Kampus Cibiru, 4(2). https://doi.org/10.17509/eh.v4i2.2827.

Hwang, G. J., Wang, S. Y., \& Lai, C. L. (2020). Effects of a Social Regulation-Based Online Learning Framework on Students' Learning Achievements and Behaviors in Mathematics. Computers and Education, 160, 104031. https://doi.org/10.1016/j.compedu.2020.104031.

Imansari, N., \& Sunaryantiningsih, I. (2017). Pengaruh Penggunaan E-Modul Interaktif terhadap Hasil Belajar Mahasiswa pada Materi Kesehatan dan Keselamatan Kerja. VOLT: Jurnal Ilmiah Pendidikan Teknik Elektro, 2(1), 11. https://doi.org/10.30870/volt.v2i1.1478.

Khachfe, H. H., Chahrour, M., Sammouri, J., Salhab, H. A., Makki, B. E., \& Fares, M. Y. (2020). An Epidemiological Study on COVID-19: A Rapidly Spreading Disease. Cureus, 12(3). https://doi.org/10.7759/cureus.7313.

Khamidah, N., Winarto, W., \& Mustikasari, V. R. (2019). Discovery Learning: Penerapan dalam Pembelajaran IPA Berbantuan Bahan Ajar Digital Interaktif untuk Meningkatkan Prestasi Belajar Siswa. JIPVA (Jurnal Pendidikan IPA Veteran), 3(1), 87. https://doi.org/10.31331/jipva.v3i1.770.

Liu, Q., Huang, J., \& Zhou, Z. (2020). Self-Expansion via Smartphone and Smartphone Addiction Tendency among Adolescents: A Moderated Mediation Model. Children and Youth Services Review, 119(June), 105590. https://doi.org/10.1016/j.childyouth.2020.105590.

Mishra, D. L., Gupta, D. T., \& Shree, D. A. (2020). Online Teaching-Learning in Higher Education during Lockdown Period of COVID-19 Pandemic. International Journal of Educational Research Open, 
100012. https://doi.org/10.1016/j.ijedro.2020.100012.

Mukramah, W., Jannah, M., \& Wahid, M. (2020). E-Modul Termodinamika Berbasis Flipbook Maker. Jurnal Pendidikan Fisika Dan Fisika Terapan, 1(3), 1-12. https://jurnal.arraniry.ac.id/index.php/jurnalphi/article/view/7752.

Nirfayanti, N., \& Nurbaeti, N. (2019). Pengaruh Media Pembelajaran Google Classroom dalam Pembelajaran Analisis Real terhadap Motivasi Belajar Mahasiswa. Proximal Jurnal Penelitian Matematika Dan Pendidikan Matematika, 2(1), 50-59. https://ejournal.my.id/proximal/article/view/211.

Novita, L., \& Novianty, A. (2020). Pengaruh Penggunaan Media Pembelajaran Audio Visual Animasi terhadap Hasil Belajar Subtema Benda Tunggal dan Campuran. JTIEE (Journal of Teaching in Elementary Education), 3(1), 46. https://doi.org/10.30587/jtiee.v3i1.1127.

Nurhidayati, A., Putro, S. C., \& Widiyaningtyas, T. (2018). Penerapan Model PBL Berbantuan E-Modul Berbasis Flipbook Dibandingkan Berbantuan Bahan Ajar Cetak Pengaruhnya terhadap Hasil Belajar Pemrograman Siswa SMK. Teknologi Dan Kejuruan: Jurnal Teknologi, Kejuruan, Dan Pengajarannya, 41(2), 130-138. https://doi.org/10.17977/um031v41i22018p130.

Oyedotun, T. D. (2020). Sudden Change of Pedagogy in Education Driven by COVID-19: Perspectives and Evaluation from a Developing Country. Research in Globalization, 2(June), 100029. https://doi.org/10.1016/j.resglo.2020.100029.

Patricia, A. (2020). College Students' Use and Acceptance of Emergency Online Learning Due to COVID-19. International Journal of Educational Research Open, 100011. https://doi.org/10.1016/j.ijedro.2020.100011.

Pramudita, Y. D., Putro, S. S., \& Makhmud, N. (2018). Klasifikasi Berita Olahraga Menggunakan Metode Naïve Bayes dengan Enhanced Confix Stripping Stemmer. Jurnal Teknologi Informasi Dan IImu Komputer, 5(3), 269. https://doi.org/10.25126/jtiik.201853810.

Pratiwi, P. H., Nur, H., \& Martiana, A. (2017). Pengembangan Modul Mata Kuliah Penilaian Pembelajaran Sosiologi Berorientasi Hots. Jurnal Cakrawala Pendidikan, 36(2), 201-209. https://doi.org/10.21831/cp.v36i2.13123.

Puspitasari, R., Hamdani, D., \& Risdianto, E. (2020). Pengembangan E-Modul Berbasis Hots Berbantuan Flipbook Marker sebagai Bahan Ajar Alternatif Siswa SMA. Jurnal Kumparan Fisika, 3(3), 247-254. https://doi.org/10.33369/jkf.3.3.247-254.

Putri, Q. K., Pratjojo, P., \& Wijayanti, A. (2019). Pengembangan Media Buku Pop-Up untuk Meningkatkan Kemampuan Menyimak Tema Menyayangi Tumbuhan dan Hewan di Sekitar. Jurnal Pedagogi Dan Pembelajaran, 2(2), 169. https://doi.org/10.23887/jp2.v2i2.17905.

Qholby, W., \& Lazulva. (2020). Pengaruh Penerapan Project Based Learning melalui Google Classroom terhadap Hasil Belajar Siswa pada Materi Laju Reaksi. Journal of Research and Education Chemistry, 2(1), 23. https://doi.org/10.25299/jrec.2020.vol2(1).4863.

Rahmanto, M. A., \& Bunyamin. (2020). Efektivitas Media Pembelajaran Daring melalui Google Classroom. Jurnal Pendidikan Islam, 11(November), 119-135. https://doi.org/10.22236/jpi.v11i2.5974.

Rahmawati, M., \& Latifah, M. (2020). Penggunaan Gawai, Interaksi Ibu-Anak, dan Perkembangan SosialEmosional Anak Prasekolah. Jur. Ilm. Kel. \& Kons., 13(1), 75-86. https://doi.org/DOI: http://dx.doi.org/10.24156/jikk.2020.13.1.75 PENGGUNAAN.

Reswita dan Sri Wahyuni. (2018). Efektivitas Media Pasir dalam Meningkatkan Kemampuan Konsep Bilangan pada Anak Usia 5-6 Tahun di TK Aisyiyah Bengkalis. Jurnal Pendidikan, 9(1).

Sahu, P. (2020). Closure of Universities Due to Coronavirus Disease 2019 (COVID-19): Impact on Education and Mental Health of Students and Academic Staff. Cureus, 2019(4), 4-9. https://doi.org/10.7759/cureus.7541.

Samaha, M., \& Hawi, N. S. (2016). Computers in Human Behavior Relationships among Smartphone Addiction, Stress, Academic Performance, and Satisfaction with Life. Computers in Human Behavior, 57, 321-325. https://doi.org/10.1016/j.chb.2015.12.045.

Samsu, N., Mustika, D., Nafaida, R., \& Manurung, N. (2020). Analisis Kelayakan dan Kepraktisan Modul Praktikum Berbasis Literasi Sains untuk Pembelajaran IPA. Jurnal IPA \& Pembelajaran IPA, 4(1), 29-40. https://doi.org/10.24815/jipi.v4i1.15546.

Soni, Hafid, A., Hayami, R., Fatma, Y., Wenando, F. A., Amien, J. Al, Fuad, E., Unik, M., Mukhtar, H., \& Hasanuddin. (2018). Optimalisasi Pemanfaatan Google Classroom sebagai Media Pembelajaran di SMK Negeri 1 Bangkinang. Jurnal Pengabdian untuk Mu NegeRI, 2(1), 1-4. https://doi.org/10.37859/jpumri.v2i1.361.

Sulistiyawati, W., Sholikhin, R. S., Afifah, D. S. N., \& Listiawan, T. L. (2021). Peranan Game Edukasi Kahoot! dalam Menunjang Pembelajaran Matematika. Wahana Matematika Dan Sains: Jurnal Matematika, Sains, dan Pembelajarannya, 15(1), 56-57. https://doi.org/10.23887/wms.v15i1.29851. 